\title{
Impact of rainwater hydrogen peroxide on chlorophyll a content of surface Gulf Stream seawater off North Carolina, USA
}

\author{
Joan D. Willey ${ }^{1, *}$, Hans W. Paerl $^{2}$, Malia Go ${ }^{2}$ \\ 'Department of Chemistry and Marine Science Program, University of North Carolina at Wilmington, 601 S. College Road, \\ Wilmington, North Carolina 28403-3297, USA \\ ${ }^{2}$ Institute of Marine Sciences, University of North Carolina at Chapel Hill, 3431 Arendell Street, Morehead City, \\ North Carolina 28557, USA
}

\begin{abstract}
Bioassays indicate addition of hydrogen peroxide in concentrations similar to rain sometimes decreases chlorophyll a ( $\mathrm{chl}$ a) production in surface Gulf Stream seawater. Bioassays were conducted on shipboard in the spring and autumn of 1993, 1994, and 1995, using surface Gulf Stream seawater collected off the coast of North Carolina. Chl a increases were observed after addition of $\mathrm{FeCl}_{3}$ (in 1 of 5 bioassays), iron (III) EDTA (6 of 6 bioassays), or EDTA alone ( 4 of 4 bioassays). The chl a increases were suppressed significantly in 7 of 11 of these bioassays when the bioassay seawater was initially diluted by $1 \%$ with a 30 or $40 \mu \mathrm{M}$ solution of hydrogen peroxide (a concentration similar to rainwater). Hydrogen peroxide induced inhibition of chl a production was not observed in bioassays in which chl $a$ increased in response to addition of nitrate or ammonium, hence the growth inhibition was associated with added metal or complexing agent. Rainwater therefore plays a complex role in primary productivity in surface seawater, with the specific effect dependent upon rainwater concentrations of nitrate, ammonium, trace metals and hydrogen peroxide, as well as on the extent of nitrogen limitation and the oxidant concentration in the surface seawater.
\end{abstract}

KEY WORDS: Hydrogen peroxide $\cdot$ Rainwater $\cdot$ Chlorophyll a $\cdot$ Bioassays $\cdot$ Gulf Stream $\cdot$ Seawater

\section{INTRODUCTION}

The Gulf Stream, with oligotrophic surface water, flows close to the North Carolina coast $(40$ to $100 \mathrm{~km})$, and so may be influenced by continental inputs transported via the atmosphere. Rainwater concentrations of the phytoplankton nutrients nitrate and ammonium vary substantially in this region (Willey \& Kiefer 1993), as do concentrations of the photochemical oxidant hydrogen peroxide (Willey et al. 1996). Hence, rain from different storms may have different impacts upon surface waters (Willey \& Cahoon 1991, Willey \& Paerl 1993).

Elevated concentrations of hydrogen peroxide have been observed in surface seawater for days following

•E-mail: willeyj@uncwil.edu rain events (Cooper et al. 1987, Miller \& Kester 1994). A light rain caused seawater hydrogen peroxide to almost double in concentration to a depth of $4 \mathrm{~m}$; model calculations indicate that increases could occur down to $50 \mathrm{~m}$ during major storms (Cooper et al. 1987). Hydrogen peroxide occurs in the gas phase in concentrations reaching several parts per billion in the study area (DeForest et al. 1997); gas exchange is also a source of hydrogen peroxide to surface seawater (Thompson \& Zafiriou 1983). Gas phase concentrations of hydrogen peroxide may increase in the near future due to changing climate and atmospheric composition (Thompson et al. 1989, Thompson 1992). If surface seawater concentrations of hydrogen peroxide increase, the solubility, speciation, and bioavailability of many trace metals, including both micronutrients and toxins, could be affected. 
Depending on concentrations, the trace metals iron, molybdenum, manganese, zinc, copper, cobalt and nickel are all seawater micronutrients. Iron, molybdenum, manganese and copper occur in more than 1 oxidation state, and different oxidation states can have solubilities that vary by many orders of magnitude. Hydrogen peroxide concentrations affect the solubilities of several of these metals through varied oxidation and reduction reactions. For example, hydrogen peroxide is a dominant oxidant for Fe(II) in seawater (Moffett \& Zika 1987, Millero \& Sotolongo 1989), an important reductant for $\mathrm{Cu}^{2+}$ (Moffett \& Zika 1983, 1987) and is involved in the $\mathrm{MnO}_{2}(\mathrm{~s})-\mathrm{Mn}^{2+}$ (aq) photochemical cycle (Sunda et al. 1983, Sunda 1988-89).

Many trace metals, including $\mathrm{Cd}, \mathrm{Pb}, \mathrm{Zn}, \mathrm{Cu}, \mathrm{Ni}, \mathrm{V}$, Fe and $M n$ are thought to be elevated in rain relative to crustal concentrations (Church et al. 1984, 1991, Jickells et al. 1984), and several of these occur in more than 1 oxidation state in aqueous solution. Rain therefore is a delivery mechanism to seawater for many trace metals (Duce et al. 1991, Jickells 1995), as well as a solubility-altering environment for certain trace metals. The objective of this study is to investigate whether rainwater hydrogen peroxide can alter chlorophyll a (chl a) production in surface Gulf Stream seawater through modification of trace metal bioavailability.

\section{METHODS}

Experimental. Six bioassays were conducted between June 1993 and September 1995 using oligotrophic Gulf Stream surface seawater (Table 1) collected within an $18 \mathrm{~km}$ radius of $33^{\circ} 42^{\prime} \mathrm{N}$ and $76^{\circ} 05^{\prime} \mathrm{W}$ (off the coast of North Carolina) during cruises of the RV 'Cape Hatteras'; exact locations depended upon the variable position of the Gulf Stream. Three bioassays were conducted in June and November of 1993, and May of 1994, with continental shelf surface seawater (salinities 35.2, 35.9 and 35.6\% respectively) approximately $100 \mathrm{~km}$ northwest of the Gulf Stream station. Bioassays were conducted using methods described extensively in Paerl et al. (1990), Willey \& Cahoon (1991), Willey \& Paerl (1993) and Paerl et al. (1994). Briefly, bioassay seawater was incubated at sea surface temperature $\left( \pm 2^{\circ} \mathrm{C}\right)$ in $4 \mathrm{l}$ polyethylene Cubitainers for 2 to $3 \mathrm{~d}$ with light intensity controlled to approximately $50 \%$ of incident by neutral density screening. At the end of each bioassay, $3.5 \mathrm{l}$ of bioassay seawater was filtered (Whatman $\mathrm{GF} / \mathrm{F}$ ) and the filters were frozen and later analyzed fluorometrically for chl a (Strickland \& Parsons 1972). Cubitainers were

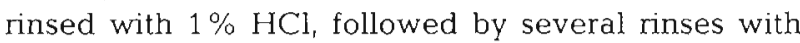
the experimental seawater prior to use. These Cubitainers had been found to be $80 \%$ transparent to photosynthetically active radiation (Paerl et al. 1990). Seawater for the bioassays was collected from $2.7 \mathrm{~m}$ using the ship's non-metallic PVC pumping system and piping. The pumping system was run for at least $2 \mathrm{~h}$ with the experimental seawater before bioassay containers were filled. Cubitainers were filled in random order. The many positive growth responses observed in these bioassays and in those done at the same times reported in Paerl et al. (in press) indicate that the potential for plankton growth was maintained with these experimental procedures.

Six separate Cubitainers containing unaltered seawater served as controls in each bioassay. Several different additions were made (each with 3 replicates) to seawater in the various experiments. Fe(III)EDTA (formed from $\mathrm{FeCl}_{3}$ and EDTA) was added to achieve a

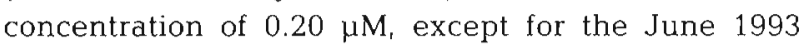
bioassays which had additions of Fe(III)EDTA of $0.50 \mu \mathrm{M}$, and the September 1995 bioassays which used a range of concentrations from 0.01 to $0.20 \mu \mathrm{M}$. $\mathrm{FeCl}_{3}$ and EDTA were also added separately in certain bioassays, to achieve a concentration of $0.20 \mu \mathrm{M}$. The EDTA was free of iron and other trace metals (K. Bruland pers. comm.); ultra pure $\mathrm{FeCl}_{3}$ (Fisher) was used to prepare the Fe(III)EDTA. Both the Fe(III)EDTA and EDTA alone should be chemically stable throughout the experimental time frame, salinity, and light

Table 1. Bioassay dates and initial seawater values for salmity $(\%)$, temperature $\left({ }^{\circ} \mathrm{C}\right)$, hydrogen peroxide $(\mu \mathrm{M})$, ammonium $(\mu \mathrm{M})$, phosphate $(\mu \mathrm{M})$, and silicate $(\mu \mathrm{M})$. Initial nitrate concentrations were $<0.2 \mu \mathrm{M}$ (June 1993 was not analyzed). Chl a ( $\mu \mathrm{g} \mathrm{l}^{-1}$ ) concentrations are from the controls after the experiment; these correspond to the $100 \%$ value for the controls in the figures. $\mathrm{NA}=$ not analyzed

\begin{tabular}{|c|c|c|c|c|c|c|c|}
\hline Date & $\begin{array}{l}\text { Sal. } \\
(\%)\}\end{array}$ & $\begin{array}{l}\text { Temp } \\
\left({ }^{\circ} \mathrm{C}\right)\end{array}$ & $\begin{array}{c}{\left[\mathrm{H}_{2} \mathrm{O}_{2}\right]} \\
(\mu \mathrm{M})\end{array}$ & $\begin{array}{c}{\left[\mathrm{NH}_{4}{ }^{+}\right]} \\
(\mu \mathrm{M})\end{array}$ & $\begin{array}{c}{\left[\mathrm{HPO}_{4}{ }^{2-}\right]} \\
(\mu \mathrm{M})\end{array}$ & $\begin{array}{c}{\left[\mathrm{H}_{4} \mathrm{SiO}_{4}\right]} \\
(\mu \mathrm{M})\end{array}$ & $\begin{array}{l}{[\mathrm{Chl} a} \\
\left(\mu \mathrm{gl}^{-1}\right)\end{array}$ \\
\hline 15-17 Jun 1993 & 35.9 & 26.6 & 0.187 & $\mathrm{NA}$ & NA & 1.24 & 0.025 \\
\hline 11-12 Nov 1993 & 36.2 & 25.1 & 0.135 & 0.21 & 0.51 & NA & 0.339 \\
\hline 7-9 Мay 1994 & 36.2 & 22.0 & 0.483 & 0.54 & 0.02 & 1.42 & 0.008 \\
\hline $16-18$ Nov 1994 & 36.1 & 27.2 & 0.320 & 0.08 & 0.03 & 1.13 & 0.187 \\
\hline 6-9 May 1995 & 36.1 & 23.7 & 0.422 & 1.15 & 0.39 & 0.94 & 0.030 \\
\hline 20-23 Sep 1995 & 36.2 & 28.8 & 0.283 & $<0.02$ & 0.04 & 1.29 & 0.048 \\
\hline
\end{tabular}


regimes of these experiments (Lockhart \& Blakeley 1975, Hudson et al. 1992, Xue et al. 1995), and also should not provide biologically available nitrogen to these experiments (Alder et al. 1990).

$\mathrm{Fe}(\mathrm{III}) E D T A$, EDTA, or $\mathrm{FeCl}_{3}(0.20 \mu \mathrm{M})$ and hydrogen peroxide were added to certain bioassays. In the hydrogen peroxide additions, seawater containing the added $\mathrm{Fe}(\mathrm{III})$ EDTA, EDTA, or $\mathrm{FeCl}_{3}$ was diluted by $1 \%$ with a $30 \mu \mathrm{M}$ (November 1993) or $40 \mu \mathrm{M}$ (all other bioassays) solution of hydrogen peroxide in Millipore Plus Ultra Pure $18 \mathrm{M} \Omega$ deionized water, which increased the bioassay seawater hydrogen peroxide concentration by 0.30 or $0.40 \mu \mathrm{M}$. Seawater with only hydrogen peroxide added at these levels showed no effect on chl a content. The concentration of hydrogen peroxide was measured initially and at the end of the 1994 bioassays; approximately $80 \%$ of the added hydrogen peroxide remained in the bioassays at the end of these experiments. A complete bioassay consisted of 6 seawater Cubitainer controls, and 3 Cubitainers each of seawater + $\mathrm{FeCl}_{3}$, seawater + EDTA, seawater + Fe(III)EDTA, seawater $+\mathrm{H}_{2} \mathrm{O}_{2}$, seawater + $\mathrm{FeCl}_{3}+\mathrm{H}_{2} \mathrm{O}_{2}$, seawater $+\mathrm{EDTA}+\mathrm{H}_{2} \mathrm{O}_{2}$, and seawater $+\mathrm{Fe}(\mathrm{III}) \mathrm{EDTA}+\mathrm{H}_{2} \mathrm{O}_{2}$, for a total of 27 Cubitainers per bioassay.

Synthetic rain was prepared to provide a uniform and representative rainwater composition for certain bioassays. Synthetic rain $(\mathrm{pH}=4.25)$ was prepared to contain $20 \mathrm{HM} \mathrm{NO}_{3}^{-}$(prepared by diluting $0.01 \mathrm{~N}$ $\mathrm{HNO}_{3}$ ), $10 \mu \mathrm{M} \mathrm{NH}{ }_{4}^{+}$(from $2.5 \mathrm{mM}\left(\mathrm{NH}_{4}\right)_{2} \mathrm{SO}_{4}$ ), $25 \mu \mathrm{M}$

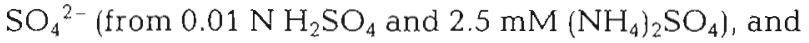
no added hydrogen peroxide. All chemicals used were Fisher, Mallinckrodt or Sigma Chemical Company reagent grade, unless otherwise described. Dilutions of stock synthetic rain solutions were made on shipboard using Millipore ultrapure deionized water. During the cruises, rain was collected on the flying bridge of the RV 'Cape Hatteras,' approximately $10 \mathrm{~m}$ above the sea surface and ahead of the stacks. Rain was collected in 3 separate precleaned (acid washed, deionized water rinsed) polyethylene bottles with funnels.

Analytical. Rain collected at sea was frozen, and later analyzed for chloride, nitrate, phosphate and sulfate using suppressed ion chromatography (Fitchett 1983). Synthetic rain stock solutions were also analyzed by suppressed ion chromatography before and after cruises, and the solutions used in the bioassays were analyzed after cruises. Rainwater and seawater were analyzed on shipboard for hydrogen peroxide using the fluorescence decay method of Kieber \& Heltz (1986). Salinity was measured at sea with a Guildline high precision salinometer. Nutrients were determined on previously frozen seawater samples using high-sensitivity colorimetric techniques described in Parsons et al. (1984).

\section{RESULTS}

The addition of dissolved $\mathrm{FeCl}_{3}$ alone produced an increase in chl $a$ in 1 out of the 5 bioassays (Figs. $1 \& 2$ ), which indicates that ferric iron is rarely a limiting nutrient in oligotrophic (Table 1) surface Gulf Stream water at this latitude. This lack of response to the addition of inorganic ferric iron may reflect the proximity of the North American continent, a source of aerosol iron to surface Gulf Stream seawater in this region (Wallace et al. 1983). Martin et al. (1993) observed that iron (added as dissolved $\left.\mathrm{Fe}\left(\mathrm{NO}_{3}\right)_{3}\right)$ acted as a growth

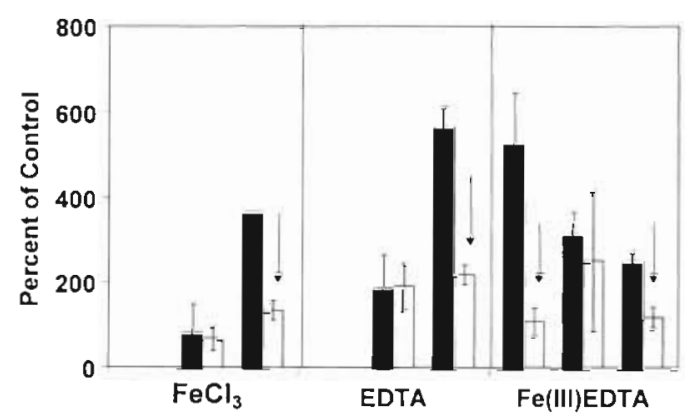

Fig. 1. Percent of chl a response relative to control in springtime bioassays conducted with surface Gulf Stream seawater in June 1993, May 1994 and May 1995 presented in chronological order. Additions to the bioassays are stated below the data; $\mathrm{FeCl}_{3}$ and EDTA were not added in the first bioassay (June 1993). The first bar in each pair (gray) gives response to the addition stated below; the second bar (white) indicates results obtained with the same addition plus hydrogen peroxide. A vertical arrow indicates a significant difference between adjacent bars $(t$-test, $p \leq 0.05)$. Error bars indicate the magnitude of 1 standard deviation. The control was unaltered seawater $(100 \pm 26 \%)$

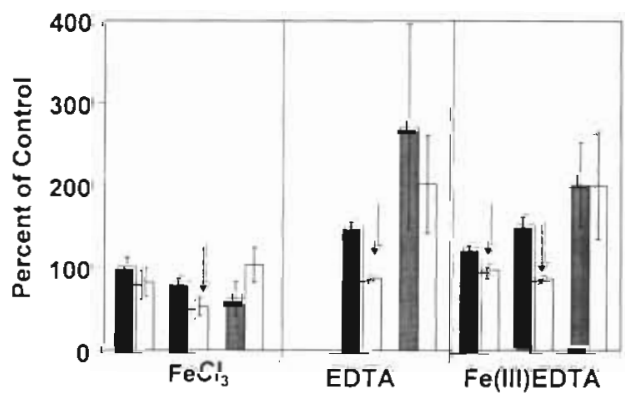

Fig. 2. Percent of chl a response relative to control in autumn bioassays conducted with surface Gulf Stream seawater in November 1993, November 1994 and September 1995 presented in chronological order. Additions to the bioassays are stated below the data; EDTA was not added in the first bioassay (November 1993). The first bar in each pair (gray) gives response to the addition stated below; the second bar (white) indicates results obtained with the same addition plus hydrogen peroxide. A vertical arrow indicates a significant difference between adjacent bars ( $t$-test, $p \leq 0.05$ ). Error bars indicate the magnitude of 1 standard deviation. The control was unaltered seawater $(100 \pm 12 \%)$ 
enhancer although it was not growth limiting in their studies in the northeast Atlantic south of Iceland. Timmermans et al. (1998) observed no direct response to iron addition (added as dissolved $\mathrm{FeCl}_{3}$ ) in the eastern Atlantic at 3 study sites all within $800 \mathrm{~km}$ of land; they did observe an increased rate of nitrate uptake after addition of $\mathrm{FeCl}_{3}$ at 1 of their sites. These Atlantic studies, with subtle phytoplankton growth responses at most, contrast with the high nutrient, low chlorophyll Equatorial Pacific surface seawater which responded dramatically to additions of dissolved inorganic ferrous or ferric iron, organically complexed ferric iron, or iron leached from aerosols (Martin et al. 1991, 1994, Johnson et al. 1994). An increase in chl a production after addition of EDTA, or iron (III) EDTA $(0.20 \mu \mathrm{M})$ was observed in all 5 Gulf Stream surface seawater bioassays (ANOVA, $p<0.01$, Figs. $1 \& 2$ ), which also indicates that the chl a response is not specifically related to iron enrichment in these experiments. Stimulation by EDTA alone has been reported for seawater in this region previously (Paerl et al. 1994). EDTA may react with particulate trace-metal-limiting nutrients to make them more available biologically (Lewin \& Chen 1971 , Anderson \& Morel 1982). EDTA may also complex. toxic trace metals and hence decrease their toxicity (Sunda et al. 1981, Sunda 1988-89, Bruland et al. 1991). These bioassays do not distinguish between these possible mechanisms.

The absolute value of the chl a increase was approximately $0.1 \mu \mathrm{g} \mathrm{l}^{-1}$ in each bioassay except May of 1994, which had a very low initial concentration (Table 1). The increases were greater in the spring bioassays compared with the autumn when expressed as percentage change (Figs. 1 \& 2). In bioassays conducted September 20 to 23 of 1995 , a chl a increase $(1.5 \times)$ was observed in response to iron (III) EDTA additions as low as $0.020 \mu \mathrm{M}$, which is comparable to surface seawater iron concentrations reported for Boston Harbor and Massachusetts Bay (Zhuang et al. 1995) and in the southeast Atlantic (Powell et al. 1995).

When $1 \%$ of a dilute solution (30 or $40 \mu \mathrm{M}$ ) of hydrogen peroxide was added to the experimental seawater, the chl a increase was often not observed (in over half of the bioassays), causing the chl a concentrations to remain the same as the controls for the duration of these experiments (Figs. $1 \& 2$ ). This hydrogen peroxide effect occurred whether the chl a response was to $\mathrm{FeCl}_{3}$ alone, EDTA alone, or Fe(III)EDTA. This lack of response was not due to salinity dilution because chl a increases have been observed following addition of synthetic rainwater without hydrogen peroxide in similar bioassay experiments (Paerl 1985, Willey \& Cahoon 1991, Willey \& Paerl 1993, Paerl et al. 1994, and Fig. 3). The hydrogen peroxide inhibition of chl a production was not observed in bioassays that re- sponded to the addition of nitrate plus ammonium in synthetic rain (Fig. 3), which suggests that the inhibition involves the iron or EDTA addition. One of the bioassays in which the hydrogen peroxide effect was not observed was the May 1994 experiment, which had the highest initial hydrogen peroxide concentration in the surface seawater. In that experiment, the addition of hydrogen peroxide increased the ambient concentration by a factor of 1.8 ; in all the other bioassays, this factor was more than 2.2. These experiments were conducted in the Gulf Stream over a 3 yr time period. The same exact results were not observed during each experiment, however the same water was not sampled each time. This temporal variability is inherent in oceanographic studies.

The concentration of hydrogen peroxide used in the experiments, 30 or $40 \mu \mathrm{M}$, is within the range of rainwater concentrations ( 0.13 to $48.4 \mu \mathrm{M}, 61$ events, Willey et al. 1996) received in nearby Wilmington, North Carolina. The Wilmington rain is similar in concentration to rain collected and analyzed at sea on these 6 cruises (5.1 to $30.5 \mu \mathrm{M}, 9$ events). Concentrations as high as $82 \mu \mathrm{M}$ have been reported in marine rain (Zika et al. 1982, Cooper et al. 1987). Rain can alter seawater hydrogen peroxide concentrations because rainwater concentrations are normally more than $100 \times$ those in surface seawater. For example, $1 \mathrm{~cm}$ of rain with $50 \mu \mathrm{M}$ hydrogen peroxide could double the hydrogen peroxide concentration of $5 \mathrm{~m}$ of seawater with $100 \mathrm{nM}$ hydrogen peroxide.

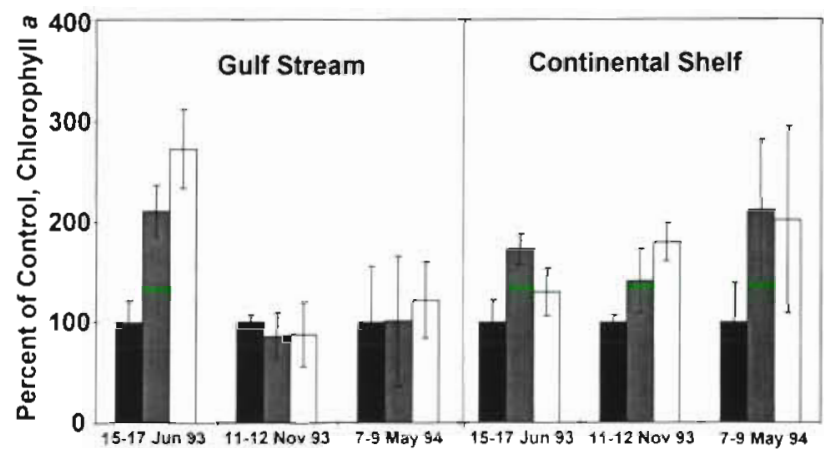

Fig. 3. Percent of chl a response relative to controls in 6 bioassays conducted with surface Gulf Stream seawater, or continental shelf water (salinities 35.2, 35.9 and $35.6 \%$ in sequence) approximately $100 \mathrm{~km}$ northwest of the Gulf Stream station, on the dates indicated. Controls (black bars) were unaltered seawater; gray bars indicate addition of synthetic rain $15 \%$ dilution in June 1993; 3\% dilution in November 1993, and May 1994); the third bars in each group (white) indicate addition of both synthetic rain (same dilutions as preceding bars) and dilute hydrogen peroxide ( $1 \%$ dilution). The chl a response to the addition of synthetic rain alone was not different in any bioassay than the response to the addition of synthetic rain plus hydrogen peroxide ( $t$-test). Error bars indicate the magnitude of 1 standard deviation 


\section{DISCUSSION}

The rainwater hydrogen peroxide enrichment of seawater in these experiments should alter the oxidation state of nutrient or toxic trace metals, thereby changing the activity of free metal ions, and hence changing biological availability. Hydrogen peroxide can act as a reductant for certain metals. For example, cupric ion is reduced by hydrogen peroxide in seawater; thermodynamic calculations indicate that $\mathrm{Cu}(\mathrm{I})$ varies from 10 to $25 \%$ of the total dissolved inorganic copper over the hydrogen peroxide concentration increase in these experiments (Moffett \& Zika 1983). Because Cu(I) forms a stable complex with chloride, it can persist for many hours before oxidation by $\mathrm{O}_{2}$ (Moffett \& Zika 1983). Reduction and subsequent dissolution of particulate $\mathrm{MnO}_{2}$ by concentrations of hydrogen peroxide in the $10^{-7} \mathrm{M}$ range has been proposed by Sunda et al. (1983). Hydrogen peroxide also acts as an oxidant for certain metals. Hydrogen peroxide in seawater rapidly oxidizes ferrous iron, forming the much less soluble ferric iron, with the rate of reaction proportional to the concentration of hydrogen peroxide (Moffett \& Zika 1983, Millero \& Sotolongo 1989). These metals do not occur independently in seawater or rainwater; competing or antagonistic reactions between toxic and biolimiting trace metals may affect seawater primary productivity differently than individual trace metals acting independently of each other (Sunda et al. 1981, Bruland et al. 1991). Trace metal reactions, mediated by hydrogen peroxide, may affect the bioavailability of certain trace metals regardless of source, whether added to surface seawater with rain or aerosol, or from upwelling or recycling.

Rainwater may therefore play a complex role in affecting primary productivity in surface seawater, with the ratio of trace metals to hydrogen peroxide in rainwater determining whether rain from a specific storm event is a source or removal mechanism for trace metals. The composition of the surface seawater receiving the rain must also be a relevant factor in biomass response to rain, especially with respect to nitrogen limitation and whether seawater is enriched or depleted with ammonium and/or nitrate (Donaghay et al. 1991, Duce et al. 1991).

Acknowledgements. This work was supported by the National Science Foundation (ATM-9320971 to J.D.W. and DEB-9210495 to H.W.P.), North Carolina Sea Grant Program (Project R/MER-30 to H.W.P.), and the Duke-University of North Carolina Oceanographic Consortium. This is contribution number 134 from the Center for Marine Science Research at the University of North Carolina at Wilmington. The crew of the RV 'Cape Hatteras' helped with the shipboard experiments. B. Peierls and T. Sharp provided analytical assistance. R. Arimoto, D. R. Kester and E. R. Sholkovitz made helpful suggestions to an earlier draft.

\section{LITERATURE CITED}

Alder AC, Siegrist H, Gujer W, Giger W (1990) Behaviour of NTA and EDTA in biological wastewater treatment. Wat Res 24(6):733-742

Anderson MA, Morel FMM (1982) The influence of aqueous iron chemistry on the uptake of iron by the coastal diatom Thalassiosira weissflogii. Limnol Oceanogr 27(5):789-813

Bruland KW, Donat JR, Hutchins DA (1991) Interactive influences of bioactive trace metals on biological production in oceanic waters. Limnol Oceanogr 36:1555-1577

Church TM, Tramontano JM, Scudlark JR, Jickells TD, Tokos, JJ Jr, Knap AH, Galloway JN (1984) The wet deposition of trace metals to the western Atlantic Ocean at the MidAtlantic coast and on Bermuda. Atmos Environ 18(12): 2657-2664

Church TM, Tramontano JM, Whelpdale DM, Andreae MO, Galloway JN, Keene WC, Knap AH, Tokos JJ Jr (1991) Atmospheric and precipitation chemistry over the north Atlantic Ocean: shipboard results, April-May, 1984. $J$ Geophys Res 96(D10):18,705-18,725

Cooper WJ, Saltzman ES, Zika RG (1987) The contribution of rainwater to variability in surface ocean hydrogen peroxide. J Geophys Res 92(C3):2970-2980

DeForest C, Kieber RJ, Willey JD (1997) Comparison of stripping coil and condensate techniques for the collection of gas phase hydrogen peroxide, with applications of condensate collection in and of the coast of North Carolina. Environ Sci Technol 31:3068-3073

Donaghay PL, Liss PS, Duce RA, Kester DR, Hanson AK, Villareal T, Tindale NW, Gifford DJ (1991) The role of episodic atmospheric nutrient inputs in the chemical and biological dynamics of oceanic ecosystems. Oceanography $4(2): 62-70$

Duce RA, Liss PJ, Merrill JT, Atlas EL, Buat-Menard P, Hicks BB, Miller JM, Prospero JM, Arimoto R, Church TM, Ellis W, Galloway JN, Hansen L, Jickells TD, Knap AH, Reinhardt KH, Schneider B, Soudine A, Tokos JJ, Tsunogai S, Wollast R, Zhou M (1991) The atmospheric input of trace species to the world ocean. Global Biogeochem Cycles $5(3): 193-259$

Fitchett. AW (1983) Analysis of rain by ion chromatography In: Campbell SA (ed) Sampling and analysis of rain, ASTM Special Technique Publication 823, Philadelphia, p $29-40$

Hudson RJM, Covault DT, Morel FMM (1992) Investigations of iron coordination and redox reactions in seawater using ${ }^{59} \mathrm{Fe}$ radiometery and ion-pair solvent extraction of amphiphilic iron complexes. Mar Chem 38:209-235

Jickells TD, Knap AH, Church TM (1984) Trace metals in Bermuda rainwater. J Geophys Res 89(D1):1423-1428

Jickells TD (1995) Atmospheric inputs of nutrients and metals to the oceans: their magnitudes and effects. Mar Chem 48: $199-214$

Johnson KS, Coale KH, Elrod VA, Tindale NW (1994) Iron photochemistry in seawater from the equatorial Pacific. Mar Chem 46:319-334

Kieber RJ, Helz RG (1986) Two method verification of hydrogen peroxide determinations in natural waters. Anal Chem 58:2312-2315

Lewin J, Chen $\mathrm{CH}$ (1971) Available iron: a limiting factor for marine phytoplankton. Limnol Oceanogr 16:670-675

Lockhardt HB, Blakeley RV (1975) Aerobic photodegradation of Fe (III) - (Ethylenedinitrilo) tetraacetate (Ferric EDTA) Environ Sci Technol 9:1035-1038

Martin JH, Gordon RM, Fitzwater SE (1991) The case for iron Limnol Oceanogr 36(8):1793-1802 
Martin JH, Fitzwater SE, Gordon RM, Hunter CN, Tanner SJ (1993) Iron, primary productivity and carbon-nitrogen flux studies during the JGOFS North Atlantic Bloom experiment. Deep-Sea Res 40:115-134

Martin JH, Coale KH, Johnson KS, Fitzwater SE, Gordon RM, Tanner SJ, Hunter CN, Elrod VA, Nowicki JL, Coley TL, Barber RT, Lindley S, Watson AJ, Van Scoy K, Law CS, Liddicoat MI, Ling $R$, Stanton $T$, Stockel J, Collins C, Anderson A, Bidigare $R$, Ondrusek $M$, Latasa $M$, Millero FJ, Lee $K$, Yao WJ, Zhang $Z$, Friederich G, Sakamoto $C_{\text {, }}$ Chavez F, Buck K, Kolber Z, Greene R, Falkowski P, Chisholm SW, Hoge $F$, Swift $R$, Yungel J, Turner $S$, Nightingale P, Hatton A, Liss P, Tindale NW (1994) Testing the iron hypothesis in ecosystems of the equatorial Pacific Ocean. Nature 371:123-129

Miller WL, Kester DR (1994) Peroxide variations in the Sargasso Sea. Mar Chem 8:17-29

Millero FJ, Sotolongo $S$ (1989) The oxidation of Fe(II) with $\mathrm{H}_{2} \mathrm{O}_{2}$ in seawater. Geochim Cosmochim Acta 53: $1867-1873$

Moffett JW, Zika RG (1983) Oxidation kinetics of Cu(I) in seawater: implications for its existence in the marine environment. Mar Chem 13:239-251

Moffett JW, Zika RG (1987) Reaction kinetics of hydrogen peroxide with copper and iron in seawater. Environ Sci Technol 21(8):804-810

Paerl HW (1985) Enhancement of primary production by nitrogen-enriched acid rain. Nature 315:747-749

Paerl HW, Rudek J, Mallin MM (1990) Stimulation of phytoplankton production in coastal waters by natural rainfall inputs: nutritional and trophic implications. Mar Biol 107: $247-254$

Paerl HW, Prufert-Bebout LE, Guo C (1994) Iron-stimulated $\mathrm{N}_{2}$ fixation and growth in natural and cultured populations of the planktonic marine cyanobacterium Trichodesmium sp. Appl Environ Microbiol 60(3):1044-1047

Paerl HW, Willey JD, Go M, Peierls BL, Pinckney JL, Fogel ML (in press) Rainfall stimulation of primary production in western Atlantic Ocean waters: roles of different nitrogen sources and co-limiting nutrients. Mar Ecol Prog Ser

Parsons TR, Maita Y, Lalli CM (1984). A manual of chemical and biological methods for seawater analysis. Pergamon Press, Oxford

Powell RT, King DW, Landing WM (1995) Iron distributions in surface waters of the south Atlantic. Mar Chem 50:13-20

Strickland JDH, Parsons TR (1972) A practical handbook of seawater analysis. Bull Fish Res Bd Can 167

Editorial responsibility: Peter J. Wangersky (Contributing Editor), Victoria, British Columbia, Canada
Sunda WG, Barber RT, Huntsman SA (1981) Phytoplankton growth in nutrient rich seawater: importance of coppermanganese cellular interactions. J Mar Res 39:567-586

Sunda WG, Huntsman SA, Ferguson RL (1983) Reduction of manganese oxides in near-surface seawater by $\mathrm{H}_{2} \mathrm{O}_{2}$. EOS $64(52): 1029$

Sunda WG (1988-89) Trace metal interactions with marine phytoplankton. Bioi Oceanog 6:411-442

Thompson AM, Zafiriou OC (1983) Air-sea fluxes of transient atmospheric species. J Geophys Res 88(C11):6696-6708

Thompson AM, Owens MA, Stewart RW (1989) Sensitivity of tropospheric hydrogen peroxide to global chemical and climate change. Geophys Res Lett 16(1):53-56

Thompson AM (1992) The oxidizing capacity of the earth's atmosphere: probable past and future changes. Science 256:1157-1165

Timmermans KR, Gledhill M, Nolting RF, Veldhuis MJW, de Baar HJW, van den Berg CMG (1998) Responses of marine phytoplankton in iron enrichment experiments in the northern North Sea and northeast Atlantic Ocean. Mar Chem 61:229-242

Wallace GT, Dudek N, Dulmage R, Mahoney O (1983) Trace element distributions in the Gulf Stream adjacent to the southeastern Atlantic continental shelf-influence of atmospheric and shelf inputs. Can J Fish Aquat Sci 40 (Suppl 2): 183-191

Willey JD, Cahoon LB (1991) Enhancement of chl a production in Gulf Stream surface seawater by rainwater nitrate. Mar Chem 34:63-75

Willey JD, Kiefer RH (1993) Atmospheric deposition in southeastern North Carolina: composition and quantity. J Elisha Mitchell Scientific Soc 109(1):1-19

Willey JD, Paerl HW (1993) Enhancement of chl a production in Gulf Stream surface seawater by synthetic versus natural rain. Mar Biol 116:329-334

Willey JD, Kieber RJ, Lancaster RD (1996) Coastal rainwater hydrogen peroxide: concentration and deposition. J Atmos Chem 25:149-165

Xue H, Sigg L, Kari FG (1995) Speciation of EDTA in natural waters: exchange kinetics of Fe-EDTA in river water. Environ Sci Technol 29:59-68

Zhuang G, Yi Z, Wallace GT (1995) Iron (II) in rainwater, snow, and surface seawater from a coastal environment. Mar Chem 50:41-50

Zika RG, Saltzman ES, Chameides WL, Davis DD (1982) $\mathrm{H}_{2} \mathrm{O}_{2}$ levels in rainwater collected in south Florida and the Bahama Islands. J Geophys Res 87:5015-5017

Submitted: January 20, 1998; Accepted: November 3, 1998 Proofs received from author(s): February 17, 1999 